Vol. 3, No. 2, 2017

\author{
Andriy Kuzyshyn ${ }^{1}$, Andriy Batig ${ }^{2}$ \\ 1 "Railway Transport Researches" Laboratory, Lviv Research Institute of Forensic Science, \\ 12, Lypynskyi Str., Lviv, Ukraine, E-mail: kuzyshyn1993@gmail.com \\ 2 "Railway Transport Researches" Laboratory, Lviv Research Institute of Forensic Science, \\ 12, Lypynskyi Str., Lviv, Ukraine, E-mail: batigasha1992@gmail.com
}

\title{
EVALUATION OF DYNAMIC CHARACTERISTICS OF DPKR-2 DIESEL TRAIN ON STRAIGHT SECTIONS OF RAILWAY TRACK
}

\author{
Received: December 12, 2017 / Revised: December 25, 2017 / Accepted: December 26, 2017
}

(C) Kuzyshyn A., Batig A., 2017

Abstract. The increase in motion speed of the trains moving along certain routs changes the operational conditions and interaction of the rolling stock and the track, and requires the solution of important issues related to the specifications of their maintenance, since there occur additional dynamic loads. In this case, the particular attention is paid to the interaction of the rolling stock and the railway track; to the problems of scientific substantiation of the criteria for assessing the dynamic characteristics of carriages; to the motion smoothness, traffic safety and travelling comfort; as well as to improvement of the maintenance specifications of the track and the rolling stock in the process of their operation and on the basis of scientific analysis and determination of top (safe) speeds of the trains motion.

Using the three-dimensional mathematical model of the DPKr-2 Diesel train waggon, its basic dynamic characteristics were determined and analysed: coefficients of vertical and horizontal dynamics, maximum acceleration of the body both in vertical and in horizontal plane. The influence of the amplitude of vertical and horizontal obliques of the railway track on the dynamic characteristics of the Diesel train was investigated. The determination of the basic dynamic characteristics was carried out on the basis of the developed three-dimensional mathematical model of the waggon, which consists of 38 differential equations of the Diesel train motion. The simulation (solving) of the mathematical model was carried out using Maple software. The geometrical periodic equivalent obliques of the left and right rails were adopted as perturbations both in vertical and in horizontal plane. The determination of the basic dynamic characteristics of the DPKr-2 Diesel trane waggon will allow evaluating its vibro-protective properties. The determination of the coefficients of vertical and horizontal dynamics both in central and in axle leaf-spring suspension, of the maximum accelerations of the waggon body in vertical and in horizontal plane will allow carrying out the analysis of vibro-protective properties of the mechanical part of the Diesel train wagon. The obtained results may be used to define the safe interval of the Diesel train motion speeds on the track sections in the presence of vertical and horizontal obliques.

Keywords: mathematical model; coefficients of vertical dynamics; coefficients of horizontal dynamics; leaf-spring suspension; wheelset.

\section{Introduction}

The designing, manufacturing, operation and repair of rolling stock are carried out in order to ensure an acceptable level of dynamic characteristics of the rolling stock during the whole lifetime [1]-[6].

The dynamic characteristics of the rolling stock mechanical part may be divided into the following categories: 1) the indicators, which evaluates the vibro-protective properties of the mechanical part [1;7]; 2) the indicators of motion safety [10]-[13].

The following indicators fall under the category of indicators, which evaluates the vibro-protective properties of the mechanical part: 1) maximum acceleration of the body; 2) maximum displacement of the body; 3 ) coefficients of vertical and horizontal dynamics. 


\section{Problem Statement}

Since the first usage of the DPKr-2 Diesel train on the Ukrainian railways, several types of testings have been conducted to verify the compliance of its characteristics with the requirements of the standardized documentation of The State Administration of Railway Transport of Ukraine "Ukrzaliznytsia". However, theoretical investigations of the train force interaction with the railway track and the determination of the basic dynamic characteristics of its mechanical part have not been carried out. In this regard, with a help of the developed mathematical model of the Diesel train waggon, it is necessary to determine and to analyse the maximum accelerations of the body, as well as the coefficients of vertical and horizontal dynamics both in central and in axle leaf-spring suspension during its motion along the straight section of the railway track.

\section{Review of Modern Information Sources on the Subject of the Paper}

It is stated in [9] that DPKr-2 Diesel train was developed in "Kryukov Railway Car Building Works" PJSC to provide suburban passenger service on the railways sections with $1520 \mathrm{~mm}$ gauge for passive passenger traffic in Ukraine, CIS countries, Latvia, Lithuania and Estonia.

Several types of tesings were performed to verify the compliance of the characteristics of the developed Diesel train with the requirements of the standardized documentation of The State Administration of Railway Transport of Ukraine "Ukrzaliznytsia". The testings of the influence of the mentioned dynamic characteristics on the track and rails switches have been carried out by "Railway Transport Researches" Laboratory in August 2014 on the main tracks of "Pridniprovska" railway.

The purpose of these investigations consists in assessment of the influence of the DPKr-2 Diesel train on the railway track and rails switches, and in determination of the top (safe) speeds of the trains motion along the railway tracks of The State Administration of Railway Transport of Ukraine "Ukrzaliznytsia" with $1520 \mathrm{~mm}$ gauge. On the basis of the obtained results of the testings, the top (safe) speeds of the DPKr-2 Diesel train motion along the railway track of $1520 \mathrm{~mm}$ gauge will be determined.

However, theoretical investigations of the DPKr-2 Diesel train force interaction with the railway track and the techniques of theoretical determination of the basic dynamic characteristics of its mechanical part are not yet available. In this regard, the mechanical model of the Diesel train waggon taking into account the basic design features of its carriage part will be considered in this article.

On the basis of the structure analysis of the waggon carriage part of the DPKr-2 Diesel train [2] and of the selected mechanical models of its basic parts, its three-dimensional mechanical model (Figs. 1-3) was constructed [5].

Considering the three projections of the mechanical model, it can be seen that the oscillations of the diesel train waggon and railway track model taken for further investigations can be described by the following generalized coordinates:

- for the waggon body: bouncing $z_{\mathrm{K}}$, jerking $x_{\mathrm{K}}$, lateral (side) drifting $y_{\mathrm{K}}$, pitching $\varphi_{\mathrm{K}}$, wobbling $\psi_{\mathrm{K}}$, lateral (side) swinging $\theta_{\mathrm{K}}$;

- for the truck frame: bouncing $z_{\mathrm{B} j}$, jerking $x_{\mathrm{B} j}$, lateral (side) drifting $y_{\mathrm{B} j}$, pitching $\varphi_{\mathrm{B} j}$, wobbling $\psi_{\mathrm{B} j}$, lateral (side) swinging $\theta_{\mathrm{B} j}(j=\overline{1,2}$ is the number of the truck frame);

- for the wheelset: bouncing $z_{\text {кпi }}$, jerking $x_{\text {кпi }}$, lateral (side) drifting $y_{\text {кпi }}$, wobbling $\psi_{\text {кпi }}$, lateral (side) swinging $\theta_{\text {кпі }}(i=\overline{1,4}$ is the number of the wheelset).

In order to describe the vibrations of the mechanical model of the diesel train waggon, a mathematical model consisting of 38 differential equations of the second order has been derived [5]. In the central stage of the waggon leaf-spring suspension, the pneumatic leaf-springs are used. In parallel to them, the hydraulic vibrations dampers are installed. 


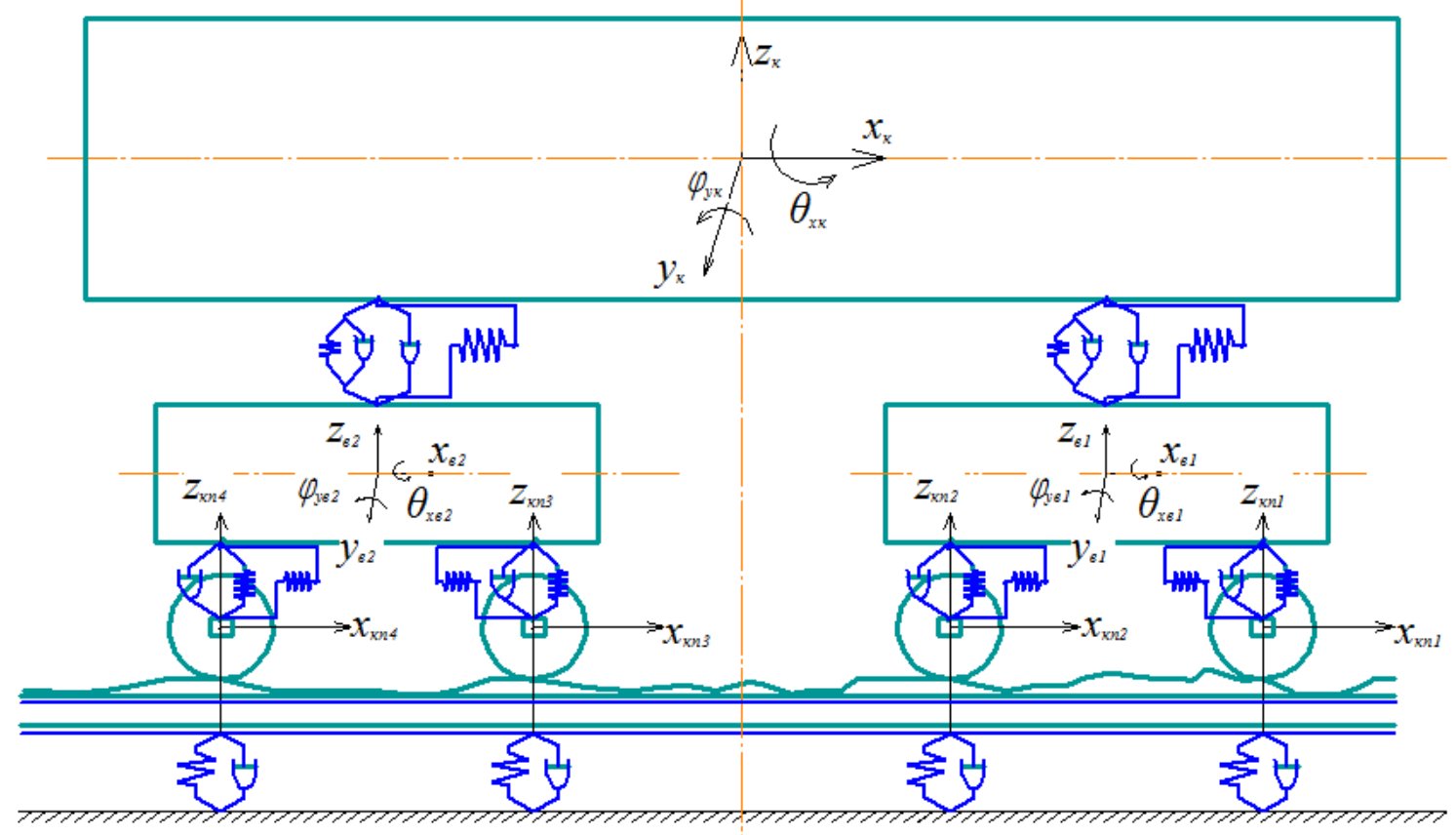

Fig. 1. Mechanical model of the DPKr-2 Diesel train waggon in projection on the plane $Z X$

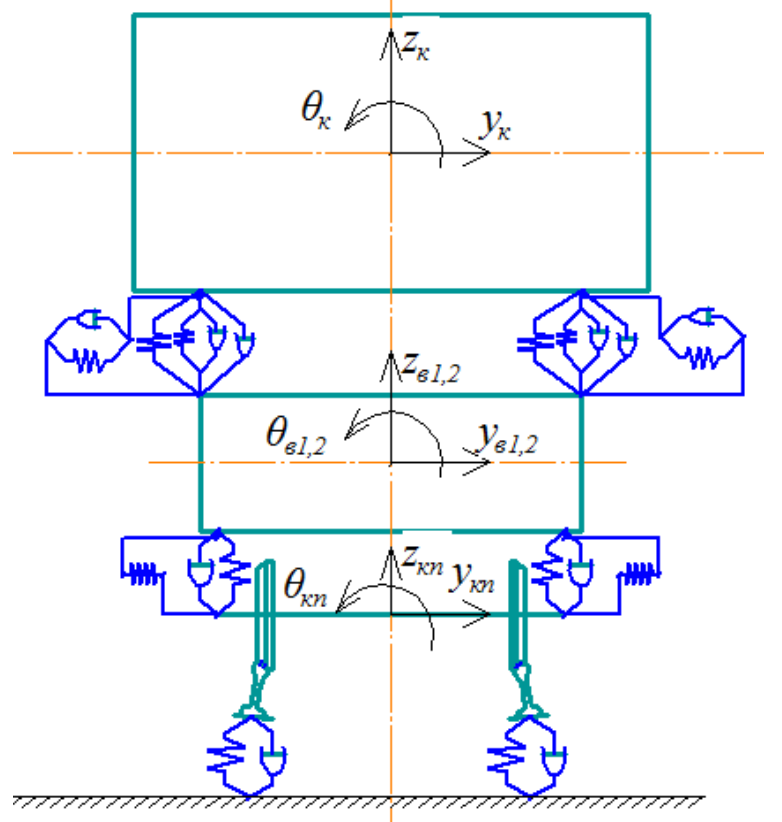

Fig. 2. Mechanical model of the DPKr-2 Diesel train waggon in projection on the plane ZY

The mathematical model of the mechanical part of the Diesel train wagon is as follows:

- wagon body bouncing:

$$
\begin{aligned}
& m_{\mathrm{K}}+4 \beta_{21} \cdot \alpha_{\mathrm{K}}+4 \beta_{2} \cdot 4 \varkappa_{21} \cdot z_{\mathrm{K}}-2 \varkappa_{21} \cdot z_{\mathrm{B} 1}-2 \varkappa_{21} \cdot z_{\mathrm{B} 2}- \\
& -2 \beta_{21} \cdot \alpha_{1}-2 \beta_{21} \cdot \alpha_{2}-2 \beta_{2} \cdot \aleph_{1}-2 \beta_{2} \cdot \&_{2}=0 \text {; }
\end{aligned}
$$

- wagon body pitching:

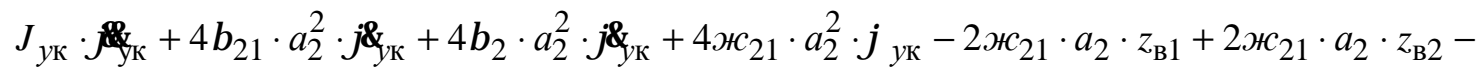

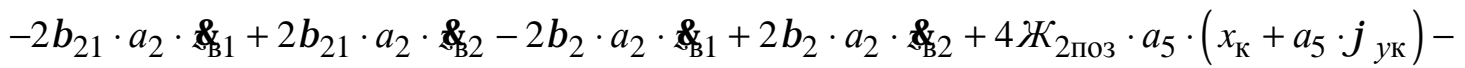

$$
-2 \mathcal{K}_{2 п о 3} \cdot a_{5} \cdot x_{\mathrm{B} 1}-2 \mathcal{K}_{2 п о 3} \cdot a_{5} \cdot x_{\mathrm{B} 2}=0 \text {; }
$$


- wagon body lateral (side) swinging:

$J_{x \mathrm{~K}} \cdot \theta_{\mathrm{K}}^{\alpha}+4 \oiint_{21} \cdot a_{3}^{2} \cdot \theta_{\mathrm{K}}+4 \beta_{21} \cdot a_{3}^{2} \cdot \theta_{\mathrm{K}}^{\alpha}+4 \beta_{2} \cdot a_{3}^{2} \cdot \theta_{\mathrm{K}}^{\alpha}+4 \oiint_{\text {тор }} \cdot a_{3}^{2} \cdot \theta_{\mathrm{K}}+4 \oiint_{2 \text { поп }} \cdot a_{5} \cdot\left(y_{\mathrm{K}}+a_{5} \cdot \theta_{\mathrm{K}}\right)+$ $+4 \beta_{2 \text { поп }} \cdot a_{5} \cdot\left(\underset{\kappa}{\alpha}+a_{5} \cdot \theta_{\mathrm{K}}^{\alpha}\right)-2 \Psi_{21} \cdot a_{3}^{2} \cdot \theta_{\mathrm{B} 1}-2 \Psi_{21} \cdot a_{3}^{2} \cdot \theta_{\mathrm{B} 2}-2 \beta_{21} \cdot a_{3}^{2} \cdot \theta_{\mathrm{B} 1}^{\alpha}-2 \beta_{21} \cdot a_{3}^{2} \cdot \theta_{\mathrm{B} 2}^{\alpha}-$ $-2 \beta_{2} \cdot a_{3}^{2} \cdot \theta_{\mathrm{B} 1}^{\alpha}-2 \beta_{2} \cdot a_{3}^{2} \cdot \theta_{\mathrm{B} 2}^{\alpha}-2 \mathcal{K}_{\text {тор }} \cdot a_{3}^{2} \cdot \theta_{\mathrm{B} 1}-2 \mathcal{K}_{\text {тор }} \cdot a_{3}^{2} \cdot \theta_{\mathrm{B} 2}-2 \mathcal{K}_{2 \text { поп }} \cdot a_{5} \cdot\left(y_{\mathrm{B} 1}-a_{6} \cdot \theta_{\mathrm{B} 1}\right)-$ $-2 \mathcal{K}_{2 \text { поп }} \cdot a_{5} \cdot\left(y_{\mathrm{B} 2}-a_{6} \cdot \theta_{\mathrm{B} 2}\right)-2 \beta_{2 \text { поп }} \cdot a_{5} \cdot\left(\oint_{\sigma_{1}}-a_{6} \cdot \theta_{\mathrm{B} 1}^{\alpha}\right)-2 \beta_{2 \text { поп }} \cdot a_{5} \cdot\left(\xi_{2}-a_{6} \cdot \theta_{\mathrm{B} 2}^{\alpha}\right)=0 ;$

- wagon body jerking:

$$
m_{\mathrm{K}} \cdot 4 \mathcal{K}_{2 \text { поз }} \cdot\left(x_{\mathrm{K}}+a_{5} \cdot \varphi_{y \mathrm{~K}}\right)-2 \mathcal{K}_{2 \text { поз }} \cdot x_{\mathrm{B} 1}-2 \mathcal{K}_{2 \text { поз }} \cdot x_{\mathrm{B} 2}=0
$$

- wagon body lateral (side) drifting:

$$
\begin{aligned}
& m_{\mathrm{K}} \cdot 4 \varkappa_{2 \text { поп }} \cdot\left(y_{\mathrm{K}}+a_{5} \cdot \theta_{\mathrm{K}}\right)+4 \beta_{2 \text { поп }} \cdot\left(a_{5} \cdot \theta_{\mathrm{K}}^{\alpha}\right)-2 Ж_{2 \text { поп }}^{\alpha} \cdot\left(y_{\mathrm{B} 1}-a_{6} \cdot \theta_{\mathrm{B} 1}\right)- \\
& -2 \mathscr{K}_{2 \text { поп }} \cdot\left(y_{\mathrm{B} 2}-a_{6} \cdot \theta_{\mathrm{B} 2}\right)-2 \beta_{2 \text { поп }} \cdot\left(\alpha_{\mathrm{B} 1}-a_{6} \cdot \theta_{\mathrm{B} 1}^{\alpha}\right)-2 \beta_{2 \text { поп }} \cdot\left(\alpha_{62}-a_{6} \cdot \theta_{\mathrm{B} 2}^{\alpha}\right)=0 \text {; }
\end{aligned}
$$

- wagon body wobbling:

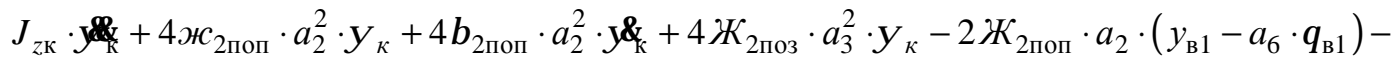

$$
\begin{aligned}
& -2 \beta_{2 \text { поп }} \cdot a_{2} \cdot\left(\alpha_{\mathrm{B} 1}-a_{6} \cdot \theta_{\mathrm{B} 1}^{\alpha}\right)+2 \mathcal{K}_{2 \text { поп }} \cdot a_{2} \cdot\left(y_{\mathrm{B} 2}-a_{6} \cdot \theta_{\mathrm{B} 2}\right)+2 \beta_{2 \text { поп }} \cdot a_{2} \cdot\left(\mathcal{\&}_{2}-a_{6} \cdot \theta_{\mathrm{B} 2}^{\alpha}\right)=0 \text {; }
\end{aligned}
$$

- first truck bouncing:

$$
m_{\mathrm{B} 1} \cdot 4 \mathcal{K}_{1} \cdot z_{\mathrm{B} 1}+4 \beta_{1} \cdot \alpha_{\mathrm{B} 1}+2 \mathcal{K}_{21} \cdot z_{\mathrm{B} 1}+2 \beta_{21} \cdot \delta_{\mathrm{B} 1}+2 \beta_{2} \cdot \oiint_{\mathrm{B} 1}-2 \mathcal{K}_{21} \cdot\left(z_{\mathrm{K}}+a_{2} \cdot \varphi_{y \mathrm{~K}}\right)-
$$

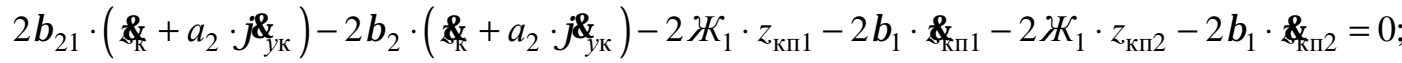

- first truck jerking:

$$
\begin{gathered}
m_{\mathrm{B} 1} \cdot 2 \nVdash_{2 \text { поз }} \cdot x_{\mathrm{B} 1}+4 \varkappa_{\text {сал.блок }} \cdot\left(x_{\mathrm{B} 1}+a_{7} \cdot \varphi_{y \mathrm{~B} 1}\right)-2 \nVdash_{2 \text { поз }} \cdot\left(x_{\mathrm{K}}+a_{5} \cdot \varphi_{y \mathrm{~K}}\right)- \\
-2 \varkappa_{\text {сал.блок }} \cdot x_{\text {кп1 } 1}-2 \varkappa_{\text {сал.блок }} \cdot x_{\text {кп2 }}=0 ;
\end{gathered}
$$

- first truck lateral (side) drifting:

$$
m_{\mathrm{B} 1} \cdot 2 \varkappa_{2 \text { поп }} \cdot\left(y_{\mathrm{B} 1}-a_{6} \cdot \theta_{\mathrm{B} 1}\right)+2 \beta_{2 \text { поп }} \cdot\left(\mathscr{\alpha}_{1}-a_{6} \cdot \theta_{\mathrm{B} 1}^{\alpha}\right)+4 \varkappa_{\text {поп }} \cdot\left(y_{\mathrm{B} 1}+a_{7} \cdot \theta_{\mathrm{B} 1}\right)-
$$

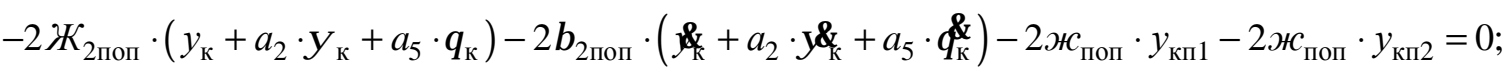

- first truck pitching:

$J_{\text {в } 1} \cdot \oiint_{\mathrm{B} 1}+4 \varkappa_{1} \cdot a_{1}^{2} \cdot \varphi_{y \mathrm{~B} 1}+4 \beta_{1} \cdot a_{1}^{2} \cdot \oint_{\mathrm{y}_{\mathrm{B}}}+4 \varkappa_{\text {сал.блок }} \cdot a_{7} \cdot\left(x_{\mathrm{B} 1}+a_{7} \cdot \varphi_{y \mathrm{~B} 1}\right)-2 \varkappa_{1} \cdot a_{1} \cdot z_{\mathrm{k \Pi 1}}-$

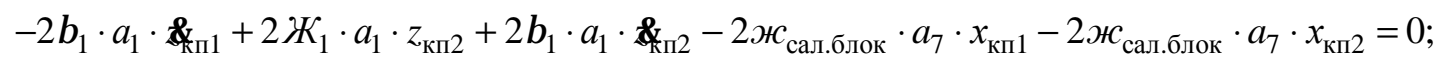

- first truck lateral (side) swinging:

$$
\begin{aligned}
& J_{x \mathrm{~B} 1} \cdot \theta_{\mathrm{B} 1}^{\alpha}+4 \varkappa_{1} \cdot a_{4}^{2} \cdot \theta_{\mathrm{B} 1}+4 \beta_{1} \cdot a_{4}^{2} \cdot \theta_{\mathrm{B} 1}^{\alpha}+4 \varkappa_{\text {поп }} \cdot a_{7} \cdot\left(y_{\mathrm{B} 1}+a_{7} \cdot \theta_{\mathrm{B} 1}\right)-2 \varkappa_{2 \text { поп }} \cdot a_{6} \cdot\left(y_{\mathrm{B} 1}-a_{6} \cdot \theta_{\mathrm{B} 1}\right)- \\
& -2 \beta_{2 \text { поп }} \cdot a_{6} \cdot\left(\mathscr{\sigma}_{\mathrm{B} 1}-a_{6} \cdot \theta_{\mathrm{B} 1}^{\alpha}\right)+2 \varkappa_{\text {тор }} \cdot a_{3}^{2} \cdot \theta_{\mathrm{B} 1}+2 \varkappa_{21} \cdot a_{3}^{2} \cdot \theta_{\mathrm{B} 1}+2 \beta_{21} \cdot a_{3}^{2} \cdot \theta_{\mathrm{B} 1}^{\alpha}+2 \beta_{2} \cdot a_{3}^{2} \cdot \theta_{\mathrm{B} 1}^{\alpha}- \\
& -2 \varkappa_{\text {тор }} \cdot a_{3}^{2} \cdot \theta_{\mathrm{K}}-2 \varkappa_{21} \cdot a_{3}^{2} \cdot \theta_{\mathrm{K}}-2 \beta_{21} \cdot a_{3}^{2} \cdot \theta_{\mathrm{K}}^{\alpha}-2 \beta_{2} \cdot a_{3}^{2} \cdot \theta_{\mathrm{K}}^{\alpha}-2 \varkappa_{1} \cdot a_{4}^{2} \cdot \theta_{\mathrm{K \Pi} 1}-2 \beta_{1} \cdot a_{4}^{2} \cdot \theta_{\mathrm{K} 11}^{\alpha}- \\
& -2 \varkappa_{1} \cdot a_{4}^{2} \cdot \theta_{\text {кп2 }}-2 \beta_{1} \cdot a_{4}^{2} \cdot \theta_{\text {кп } 2}^{\&}-2 \varkappa_{\text {поп }} \cdot a_{7} \cdot y_{\text {кп1 }}-2 \varkappa_{\text {поп }} \cdot a_{7} \cdot y_{\text {кп2 }}+ \\
& +2 \varkappa_{2 \text { поп }} \cdot a_{6} \cdot\left(y_{\mathrm{K}}+a_{2} \cdot \psi_{\mathrm{K}}+a_{5} \cdot \theta_{\mathrm{K}}\right)+2 \beta_{2 \text { поп }} \cdot a_{6} \cdot\left(\underset{\kappa}{\alpha}+a_{2} \cdot \psi \alpha_{\mathrm{K}}+a_{5} \cdot \theta_{\mathrm{K}}^{\alpha}\right)=0 ;
\end{aligned}
$$

- first truck wobbling:

$$
\begin{aligned}
& J_{z \mathrm{~B} 1} \cdot \psi_{1}+2 \varkappa_{2 \text { поз }} \cdot a_{3}^{2} \cdot \psi_{\text {в } 1}+4 \varkappa_{\text {поп }} \cdot a_{1}^{2} \cdot \psi_{\text {в } 1}+4 \varkappa_{\text {сал.блок }} \cdot a_{4}^{2} \cdot \psi_{\text {в } 1}-2 \varkappa_{\text {поп }} \cdot a_{1} \cdot y_{\text {кп1 }}+ \\
& +2 \varkappa_{\text {поп }} \cdot a_{1} \cdot y_{\text {кп2 } 2}-2 \varkappa_{\text {сал.блок }} \cdot a_{4}^{2} \cdot \psi_{\text {кп1 } 1}-2 \varkappa_{\text {сал.блок }} \cdot a_{4}^{2} \cdot \psi_{\text {кп2 } 2}-2 \varkappa_{2 п о 3} \cdot a_{3}^{2} \cdot \psi_{\text {к }}=0 ;
\end{aligned}
$$

- first wheelset bouncing:

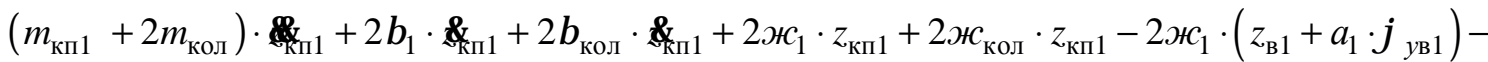

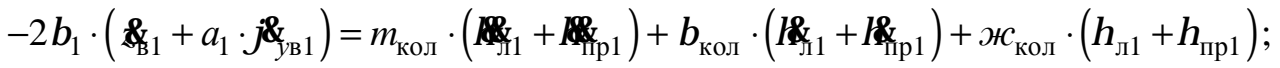


- first wheelset jerking:

$$
m_{\text {кп1 }} \cdot \varkappa_{\text {сал.блок }} \cdot x_{\text {кп1 }}-2 \varkappa_{\text {сал.блок }} \cdot\left(x_{\text {в } 1}+a_{7} \cdot \varphi_{y \mathrm{~B} 1}\right)=F_{x 1}+F_{x 2} \text {; }
$$

- first wheelset lateral (side) drifting:

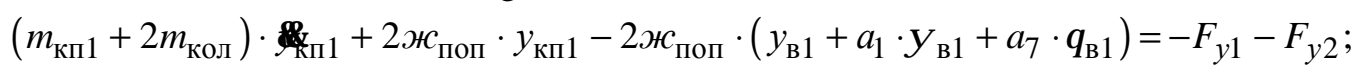

- first wheelset lateral (side) swinging:

$$
\begin{aligned}
& J_{x \text { кп1 }} \cdot \theta_{\text {Кп } 1}^{\alpha}+2 \beta_{1} \cdot a_{4}^{2} \cdot \theta_{\mathrm{K \Pi} 1}^{\alpha}+2 \beta_{\text {кол }} \cdot s^{2} \cdot \theta_{\text {Кп1 }}^{\alpha}+2 \varkappa_{1} \cdot a_{4}^{2} \cdot \theta_{\text {кп1 }}+2 \varkappa_{\text {кол }} \cdot s^{2} \cdot \theta_{\text {кп1 }}-2 \beta_{1} \cdot a_{4}^{2} \cdot \theta_{\mathrm{B} 1}^{\alpha}-
\end{aligned}
$$

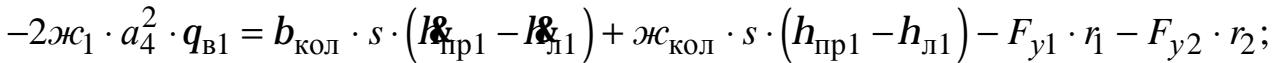

- first wheelset wobbling:

$$
J_{z \text { кп1 }} \cdot \varangle_{\text {кп1 }}+2 \varkappa_{\text {сал.блок }} \cdot a_{4}^{2} \cdot \psi_{\text {кп1 }}-2 \varkappa_{\text {сал.блок }} \cdot a_{4}^{2} \cdot \psi_{\text {в } 1}=\left(F_{x 2}-F_{x 1}\right) \cdot s .
$$

All the parameters of the mathematical model presented above are minutely specified in [5]. Let us adduce only several inertial and stiffness parameters of the DPKr-2 Diesel train waggon:

- the moments of inertia of the body and the truck about $X, Y, Z$ axes: $J_{\mathrm{XK}}=121,43 t \cdot \mathrm{m}^{2}$, $J_{\text {хв }}=5 t \cdot m^{2}, J_{\text {ук }}=1570,21 t \cdot m^{2}, \quad J_{\text {ув }}=6,6 t \cdot m^{2}, \quad J_{\text {乙к }}=1570,21 t \cdot m^{2}, \quad J_{\text {zв }}=10 t \cdot m^{2}$;

- vertical and lateral stiffness of the axle suspension springs: $\mathscr{K}_{1}=1136,6 \frac{\mathrm{kN}}{\mathrm{m}}, \varkappa_{\text {поп }}=1403,5 \frac{\mathrm{kN}}{\mathrm{m}}$.

The moments of inertia of the wheelset are presented in literature $[10 ; 11]$.

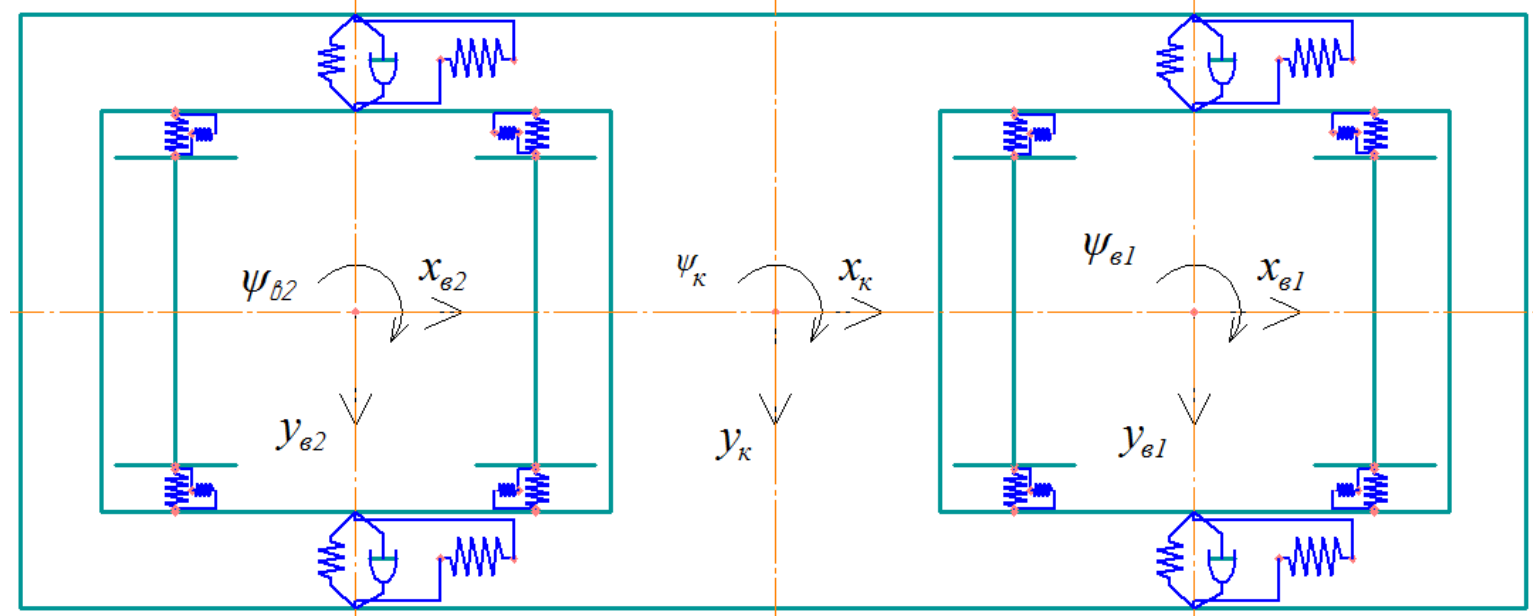

Fig. 3. Mechanical model of the DPKr-2 Diesel train waggon in projection on the plane $Y X$

\section{Objectives and Problems of Research}

On the basis of the three-dimensional mathematical model of the DPKr-2 Diesel train waggon, we will determine and analyse its main dynamic characteristics, using which one will be able to evaluate the vibro-protective properties of the rolling stock. To achieve this goal, the following tasks must be solved:

- to analyse the previously developed three-dimensional mathematical model of the waggon vibrations of the new rolling stock taking into account the features of the interaction of separate elements of its structure;

- to determine the coefficients of vertical and horizontal dynamics of the body and of the cushioned parts of the truck;

- to calculate the maximum accelerations of the body both in vertical and horizontal plane;

- to investigate the influence of the amplitudes of the rail track obliques on the dynamic characteristics of the DPKr-2 Diesel train waggon. 


\section{Main Material Presentation}

The coefficients of vertical $K_{Д}^{B}$ and horizontal $K_{Д}^{\Gamma}$ dynamics may be determined on the basis of deflexions of separate sets of leaf-spring cushion $\Delta$ :

$$
\begin{gathered}
K_{Д \Pi}^{B}=\frac{\Delta_{Д}^{B}}{\Delta_{C T}} ; \\
K_{Д \Pi}^{\Gamma}=\frac{\Delta_{Д}^{\Gamma}}{\Delta_{C T}} .
\end{gathered}
$$

In addition, they may be defined taking into account the forces $F$ occurring in separate set of leafspring cushion:

$$
\begin{gathered}
K_{Д F}^{B}=\frac{F_{Д}^{B}}{F_{C T}} ; \\
K_{Д F}^{\Gamma}=\frac{F_{Д}^{\Gamma}}{F_{C T}},
\end{gathered}
$$

In this case, dynamic coefficients have the lower index (subscript) " $Д$ "; static coefficients have the lower index (subscript) " $C T$ ". Vertical deflexions and forces have the upper index (superscript) " $B$ "; horizontal deflexions and forces have the upper index (superscript) " $\Gamma$ ".

The maximum accelerations of the wagon body characterizing the dynamic forces, which act upon the equipment placed on the rolling stock, should be determined both in vertical and in horizontal planes.

The simulation of the mathematical model of Diesel train will be carried out in Maple software.

As perturbations both in vertical and in horizontal planes, the geometrical equivalent obliques of the left and right rails are adopted:

$$
\begin{aligned}
& \eta_{\text {вер }}=H_{\text {вер }} \sin v_{1} t ; \\
& \eta_{\text {гор }}=H_{\text {гор }} \sin v_{2} t .
\end{aligned}
$$

where

$$
\begin{aligned}
& v_{1}=\frac{2 \pi}{L_{\text {вер }}} v ; \\
& v_{2}=\frac{2 \pi}{L_{\text {гор }}} v ;
\end{aligned}
$$

$H_{\text {вер }}, H_{\text {гор }}$ are the amplitudes of vertical and horizontal obliques; $L_{\text {вер }}, L_{\text {гор }}$ are the lengths of vertical and horizontal obliques; $v$ is motion speed.

The obtained results are presented in Figs. 4-11. In the mentioned figures, the dependencies of the coefficients of vertical and horizontal dynamics of the waggon body and truck as functions of the path length are presented for different parameters of the railway track obliques.

In is necessary to take into account the standardized values of the coefficients being investigated for the passenger wagon body [8]:

- the coefficients of vertical dynamics should not exceed 0.25 ;

- the coefficients of horizontal dynamics should not exceed 0.15 ;

- maximum accelerations of the body in vertical plane as a proportion of the coefficient of free fall acceleration $g$ should not exceed 0.25 ;

- maximum accelerations of the body in horizontal plane as a proportion of the coefficient of free fall acceleration $g$ should not exceed 0.15 . 


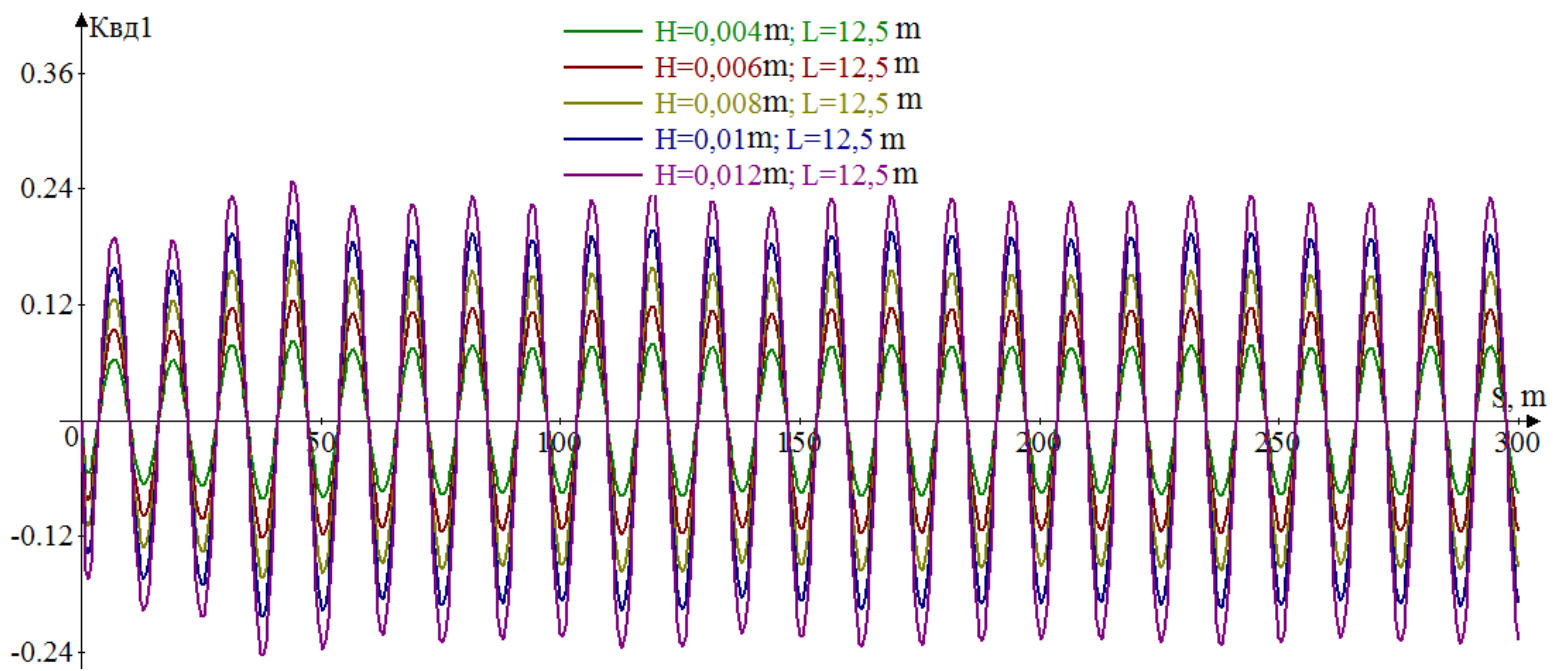

Fig. 4. Coefficients of vertical dynamics of the $1^{\text {st }}$ axle unit at the motion speed of $25 \mathrm{~m} / \mathrm{s}$

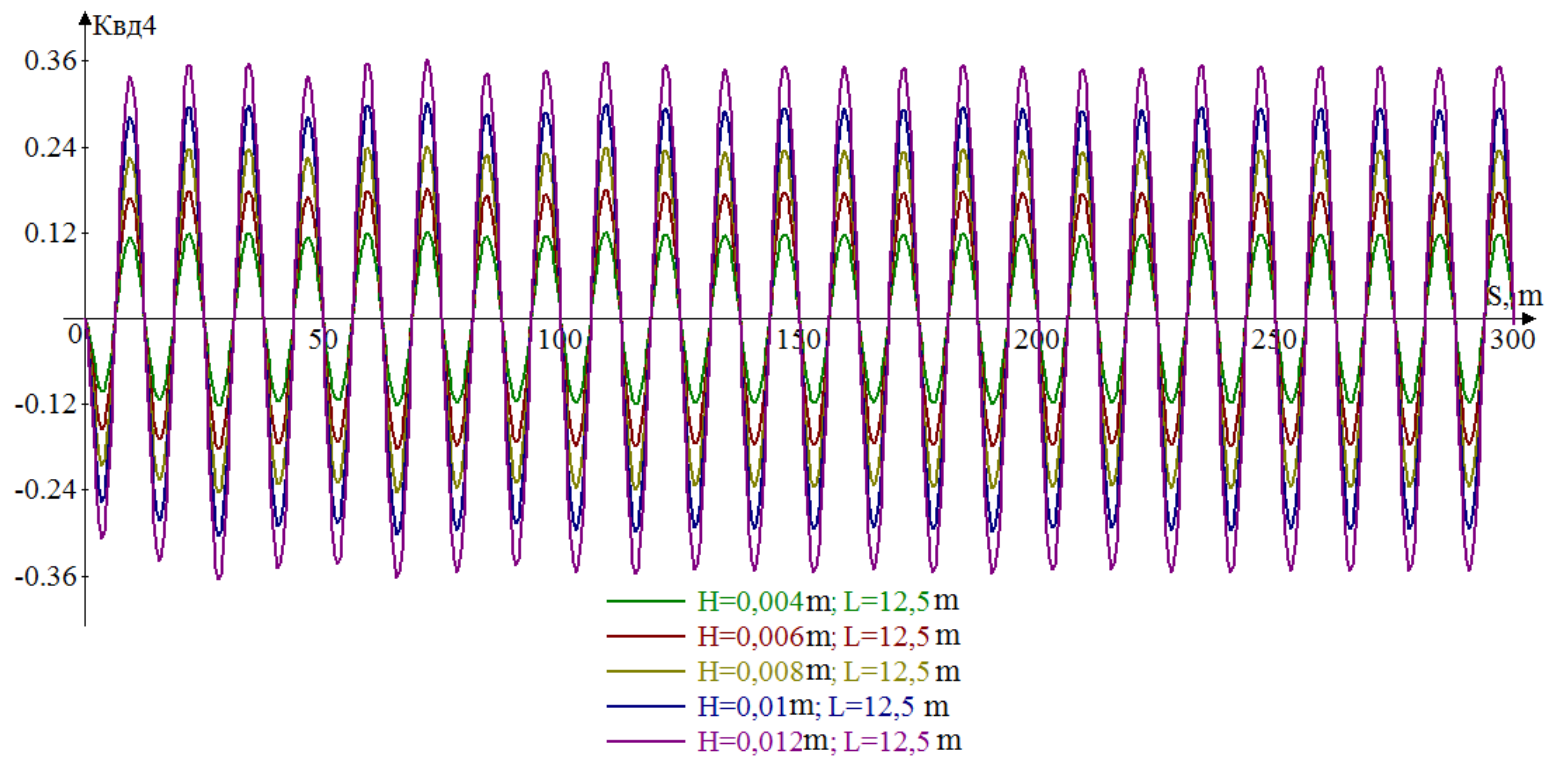

Fig. 5. Coefficients of vertical dynamics of the $4^{\text {th }}$ axle unit at the motion speed of $25 \mathrm{~m} / \mathrm{s}$
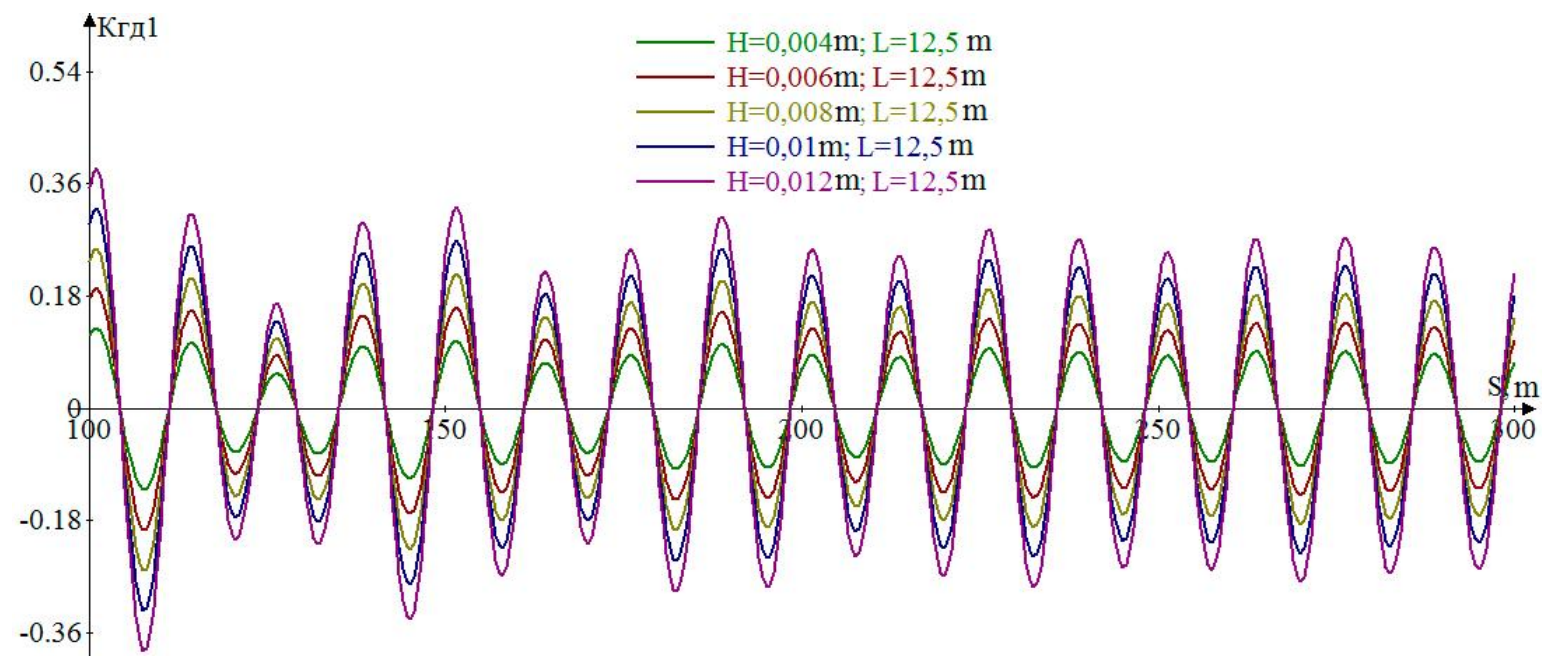

Fig. 6. Coefficients of horizontal dynamics of the $1^{\text {st }}$ axle unit at the motion speed of $25 \mathrm{~m} / \mathrm{s}$ 


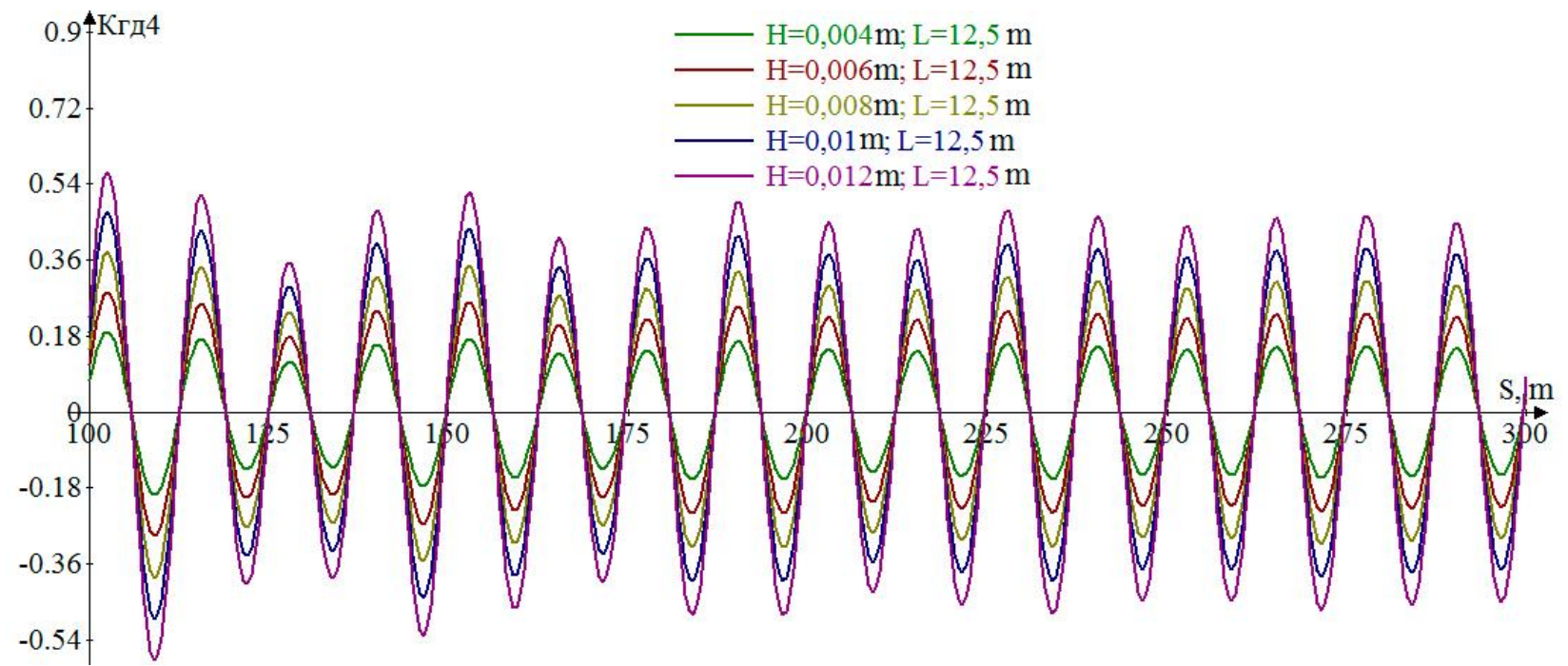

Fig. 7. Coefficients of horizontal dynamics of the $4^{\text {th }}$ axle unit at the motion speed of $25 \mathrm{~m} / \mathrm{s}$
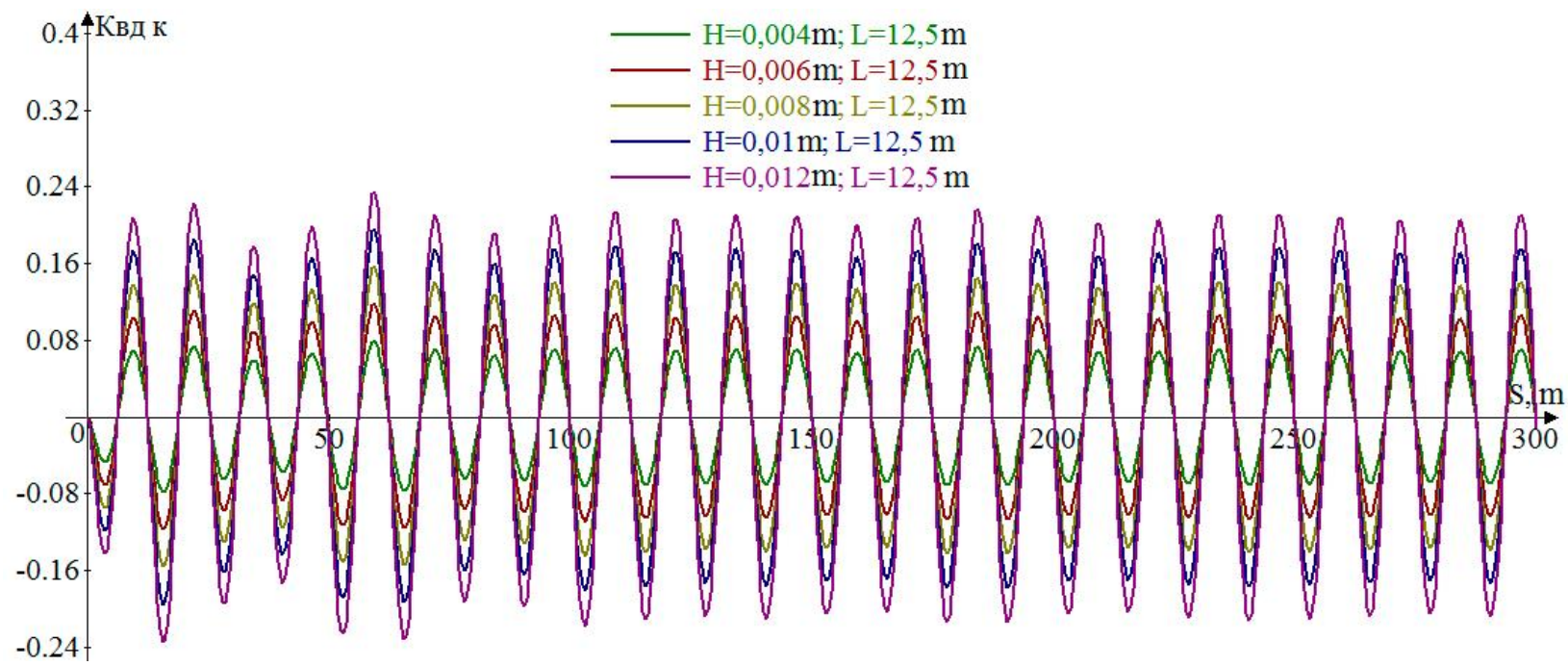

Fig. 8. Coefficients of vertical dynamics of the waggon body at the motion speed of $25 \mathrm{~m} / \mathrm{s}$

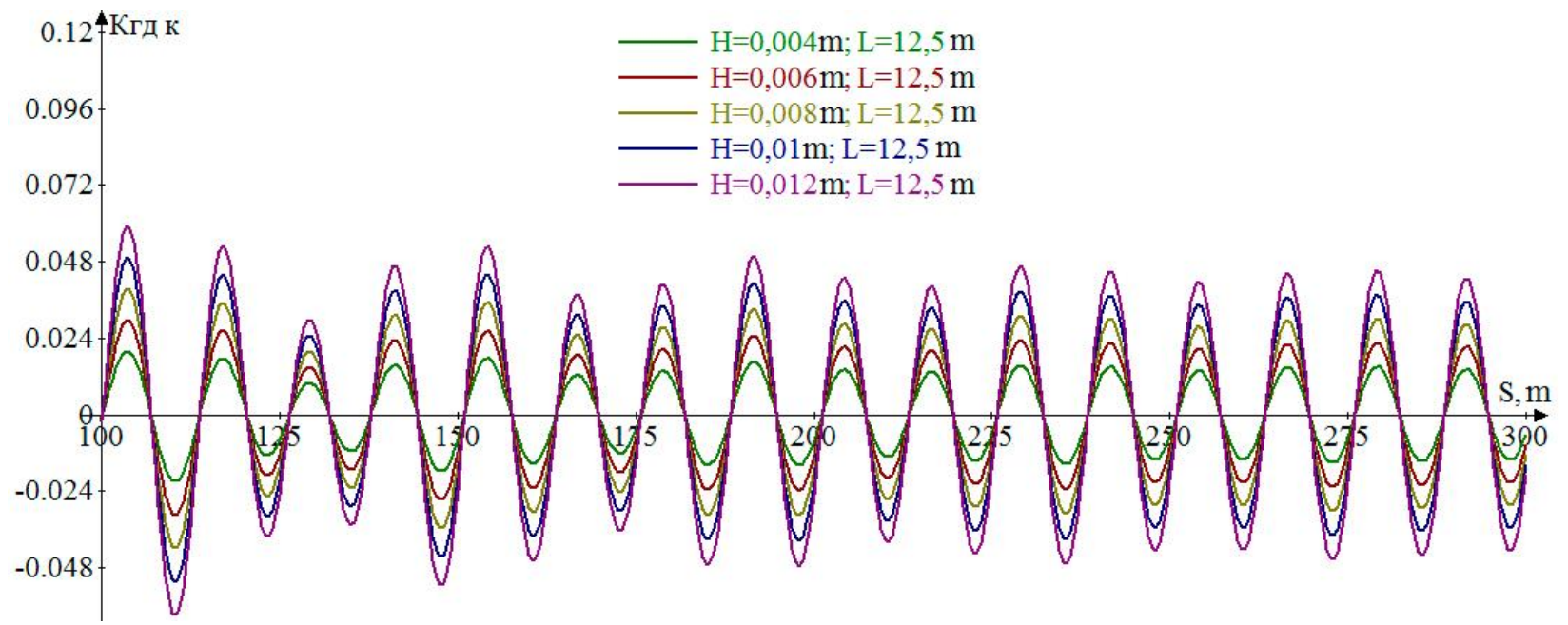

Fig. 9. Coefficients of horizontal dynamics of the waggon body at the motion speed of $25 \mathrm{~m} / \mathrm{s}$ 
In addition, let us mention the standardized values of the coefficients being investigated for the axle cushion [8]:

- the coefficients of vertical dynamics should not exceed 0.4 ;

- the coefficients of horizontal dynamics should not exceed 0.3.

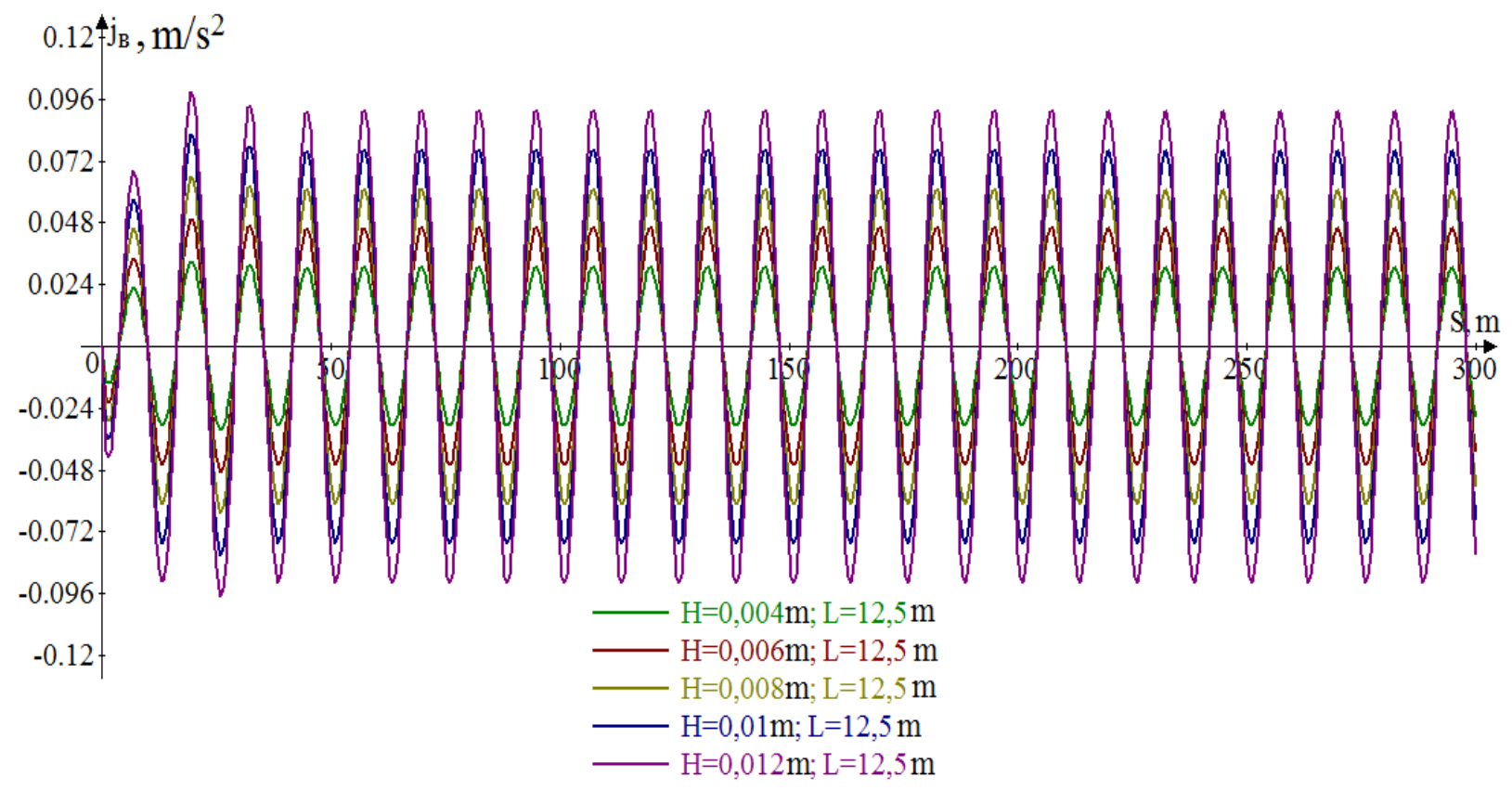

Fig. 10. Vertical accelerations of the waggon body as a proportion of the coefficient of free fall acceleration $g$

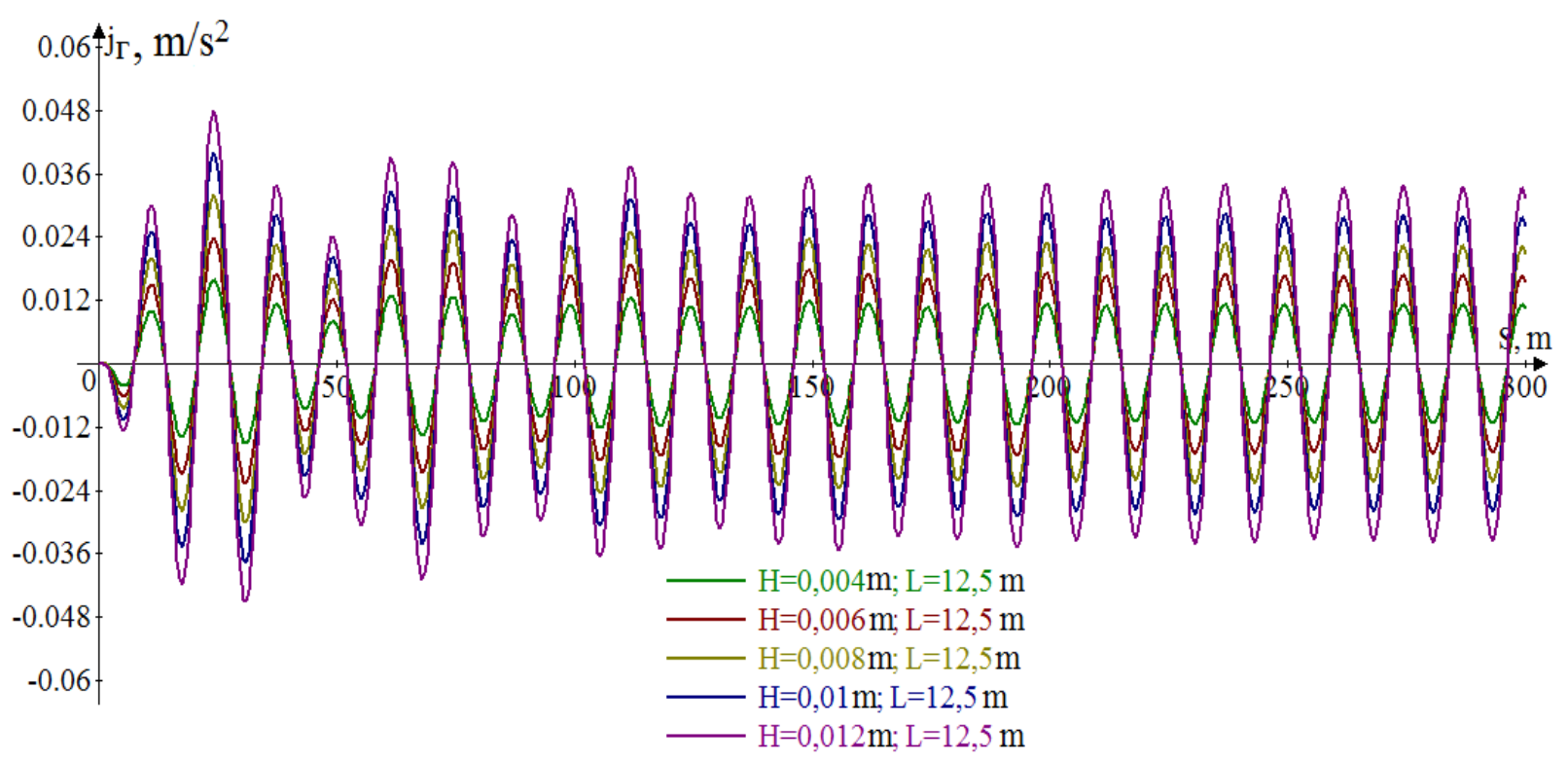

Fig. 11. Horizontal accelerations of the waggon body as a proportion of the coefficient of free fall acceleration $g$

Thus, analysing the obtained results (Figs. 4-11), and comparing them with the requirements of the standards and specifications, we may make the following conclusions:

- the increase of the numeric value of the vertical and horizontal oblique amplitudes causes the degradation of the dynamic characteristics of the Diesel train waggon;

- at certain parameters of the geometrical obliques, the coefficients of vertical and horizontal dynamics may fall outside the permissible limits. In such cases, at certain sections of the track, the slow orders (speed limitations) are made or the railway track obliques are to be corrected. 


\section{Conclusions}

1. The three-dimensional mathematical model of vibrations of new rolling stock is analysed taking into account the peculiarities of interaction of separate elements of its structure.

2. Using Maple software, the software environment, which allows taking into account the real operation conditions and geometrical tolerances during the manufacturing and repairing of the rolling stock, was developed.

3. Basic dynamic characteristics (coefficients of vertical and horizontal dynamics both in central and in axle leaf-spring cushion; maximum accelerations of the waggon body in vertical and horizontal plane) were defined.

4. For the particular case, the parameters of the railway track obliques, at which the coefficients of vertical and horizontal dynamics may fall outside the permissible limits sometimes causing the motion safety violation or rolling stock derailment, were determined.

\section{Acknowledgements}

The research was carried out in accordance with the scientific and research works of Lviv Research Institute of Forensic Science "Technique of determination of the lateral and frame forces acting on wheelsets of electric locomotives with a uniform crew section on curved sections of the track" and "Investigation of motion safety criteria on railway transport".

\section{References}

[1] S. V. Vershinskij, V. N. Danilov and V. D. Husidov, Dinamika vagonov [Waggons dynamics]. Moscow, Russia: Transport Publ., 1991. (In Russian).

[2] Dizel-poyezd passazhirskiy DPKr-2: rukovodstvo po ekspluatatsii [Passenger Diesel Train DPKr-2: Instruction manual], DPKr-2.000.000 RE, 2014. (in Russian)

[3] V. V. Trofimovich, Dinamika jelektropodvizhnogo sostava [Dynamics of electric rolling stock]. Habarovsk, Russia: DVGUPS Publ., 2004. (In Russian).

[4] M. A. Ibragimov, et al., Dinamika lokomotivov [Dynamics of locomotives]. Moscow, Russia: RGOTUPS Publ., 2005. (In Russian).

[5] A. Y. Kuzyshyn and A. V. Batig, "Pobudova mekhanichnoi modeli vahona dyzel-poizda DPKr-2 ta yii osoblyvosti" ["Construction of mechanical model of the Diesel-train DTKr-2 car and its features"], Nauka ta prohres transportu. Visnyk Dnipropetrovskoho natsionalnoho universytetu zaliznychnoho transportu [Science and Transport Progress. Bulletin of Dnipropetrovsk National University of Railway Transport], vol. 6 (72), pp. 20-30, 2017. (in Ukrainian).

[6] A. S. Maznev and A. M. Evstaf'ev, Konstrukcii i dinamika jelektricheskogo podvizhnogo sostava [Structures and dynamics of electric rolling stock]. Moscow, Russia: FGBOU "Uchebno-metodicheskij centr po obrazovaniju na zheleznodorozhnom transporte" Publ., 2013. (In Russian).

[7] I. E. Martynov, et al., "Doslidzhennia dynamichnykh navantazhen, shcho diiut na vizky pasazhyrskykh vahoniv novoho pokolinnia" ["Investigation of dynamic loads acting on the trucks of new generation of passenger waggons"], Zbirnyk naukovykh prats Ukrainskoho derzhavnoho universytetu zaliznychnoho transportu [Collected scientific works of Ukrainian State University of Railway Transport], vol. 6 (72), pp. 20-30, 2013. (in Ukrainian).

[8] Normy rascheta i ocenki prochnosti nesushhih jelementov i dinamicheskih kachestv jekipazhnoj chasti motorvagonnogo podvizhnogo sostava zheleznyh dorog MPS RF kolei $1520 \mathrm{~mm}$ [The norms of calculation and evaluation of the strength of the bearing elements and the dynamic qualities of the crew section of the motor-rail rolling stock of the Russian Railways with 1520 mm gauge]. Moscow, Russia: VNIIZhT RF Publ., 1997. (In Russian).

[9] V. Savluk, "Istoriia, dosiahnennia ta perspektyvy koliievyprobuvalnoi haluzevoi naukovo-doslidnoi laboratorii DNUZT" ["History, achievements and perspectives of the track-testing branch scientific and research laboratory DNUZT"], Ukrainski zaliznytsi [Ukrainian railways], vol. 10 (16), pp. 50-55, 2014. (in Ukrainian).

[10] Je. N. Sokol, Krushenija zheleznodorozhnyh poezdov (Sudebnaja jekspertiza. Jelementy teorii i praktiki) [Railway train crashes (Forensic examination. Elements of theory and practice)]. Kyiv, Ukraine: Feniks Publ., 2007. (In Russian).

[11] E. Kardas-Cinal, "Selected problems in railway vehicle dynamics related to running safety", The archives of transport, vol. 31, issue 3, pp. 37-45, 2014.

[12] M. Opala, "Analysis of experimental data in the context of safety against derailment of a railway vehicle, using the energy method", Key Engineering Materials, vol. 518, issue 3, pp. 16-23, 2012. 